\title{
Vascular mortality in patients with gout and in their families
}

\author{
L. G. DARLINGTON $,{ }^{1} \mathrm{~J} . \mathrm{SLACK},{ }^{2}$ AND J. T. SCOTT ${ }^{3}$ \\ From the ${ }^{1}$ Epsom Rheumatology Unit, Epsom District Hospital; the ${ }^{2}$ Clinical Genetics Unit, Institute of Child \\ Health, London; and the ${ }^{3}$ Kennedy Institute of Rheumatology and Charing Cross Hospital, London
}

SUMMARY A mortality study was performed to determine death rates from coronary and cerebrovascular pathology in 180 patients with gout and their families. Lipid profiles were also analysed. Neither male nor female gout patients after presentation to hospital nor their male or female first-degree relatives were found to have an increased risk of dying from coronary artery or cerebrovascular disease. Families of hyperlipidaemic gout patients had a slightly increased incidence among males of death from coronary artery disease, a finding which may reflect the hypercholesterolaemia found among these relatives. It could have influenced the vascular mortality rate in families of hyperlipidaemic gout patients without any relationship to the diagnosis of gout itself.

Patients with gout theoretically should be at greater risk from vascular disease than the normal population, since as a group they carry the risk factors of hypertension, hyperlipidaemia, obesity, and the possible risk factor of hyperuricaemia. ${ }^{1-3}$

The role of hyperuricaemia in the genesis of vascular disease is still under discussion. Ungerleider ${ }^{4}$ reported normal mortality in gout, as did Talbott and Lilienfeld. ${ }^{5}$ Although the Framingham Heart Study ${ }^{6}$ and the study by Ogryzlo ${ }^{7}$ found an increased risk of vascular disease in hyperuricaemic patients, the exclusion of patients with gout abolished the effect of hyperuricaemia on mortality. In addition neither of these studies was designed specifically to look at gout patients, and the implications of gout patients' various risk factors for the genesis of vascular disease have so far received scant attention.

\section{Method and materials}

To determine whether the vascular risk factors of gout patients increase their risk of dying from coronary and/or cerebrovascular disease a mortality study was designed. Families of gout patients attending the Kennedy Institute of Rheumatology and diagnosed by the usual, clinically accepted criteria were included while taking part in a family study to investigate the hyperlipidaemia associated with gout. ${ }^{8}$ The

Accepted for publication 1 April 1982.

Correspondence to Dr L. G. Darlington, Epsom District Hospital, Dorking Road, Epsom, Surrey KT18 7EG. gout patients as a group had been hyperuricaemic before treatment, but most had subsequently been treated with hypouricaemic agents.

A pedigree was taken from each of the 169 male and 11 female index gout patients taking part in a family study. The pedigree included details of the age and cause and place of death of all gout patients and their first-degree relatives who had died. Death certificates were sought from all dead, gouty index patients and all their dead, first-degree relatives to confirm the cause of death and to minimise errors due to incorrect information obtained from relatives.

Years 'at risk of dying' were determined for male and female index patients and male and female firstdegree relatives by the construction of life tables according to the method of Slack and Evans. ${ }^{9}$ The life tables were constructed with vertical columns which accounted for successive 5-year periods from 1900 onwards, and subjects were entered in the relevant column when they reached the age of 20 years, that is, the earliest time at which they could be expected to be at risk from coronary or cerebrovascular disease.

The tables had horizontal 10-year strata, and subjects were entered into consecutive strata until their death. Deceased subjects left the table midway through the appropriate 10-year stratum, and deaths due to coronary or cerebrovascular disease were specifically noted. Before 1930 the classification and diagnosis of coronary and cerebrovascular disease were not sufficiently precise for this study, and therefore no use was made of certificates issued before 1930 , and the life experience of subjects before 1930 
was excluded. Living patients left the table in 1977 and were scored as being at 1974 to allow comparison with the most recent data from the RegistrarGeneral. Those who had reached 75 years or over were allowed a life expectancy corresponding to that given in the National Life Tables instead of a 10-year span (e.g., 1930-45 life expectancy for men $=6 \cdot 4$ years and for women $=8 \cdot 1$ years, $1956-64$ for men $=$ $7 \cdot 1$ years and for women $=8 \cdot 8$ years). In this way it was possible to calculate the number of man-years during which the patients and relatives were at risk of dying.

The Registrar-General's tables were used to give the risks of dying from coronary heart disease and cerebrovascular disease at 5-yearly intervals from 1930 to the present. For each 5-year period the risks of death in the general population in the diagnostic categories mentioned were calculated for age groups 20-34, 35-44, 45-54, 55-64, 65-74, and 75 and over by means of the mortality rate per million population published in the Office of Population Censuses and Surveys' mortality statistics. Thus the risks of death were known for the general population and were considered, therefore, for each diagnostic category and each age group to be the expected number of

Table 1 Age and cause of death in gout patients

\begin{tabular}{|c|c|c|}
\hline $\begin{array}{l}\text { Gout } \\
\text { patient }\end{array}$ & $\begin{array}{l}\text { Age at } \\
\text { death }\end{array}$ & Cause of deat ${ }^{*}$ \\
\hline \multicolumn{3}{|l|}{ Male } \\
\hline 1 & 60 & $\begin{array}{l}\text { Pulmonary embolus and carcinoma of } \\
\text { stomach }\end{array}$ \\
\hline 2 & 74 & Bronchopneumonia \\
\hline 3 & 79 & $\begin{array}{l}\text { Bronchitis, emphysema and myocardial } \\
\text { degeneration }\end{array}$ \\
\hline 4 & 69 & Coronary thrombosis \\
\hline 5 & 30 & Road traffic accident \\
\hline 6 & 64 & Congestive cardiac failure \\
\hline 7 & 69 & Carcinoma of lung and bronchopneumonia \\
\hline 8 & 73 & Myocardial infarction \\
\hline 9 & 66 & Myocardial infarction \\
\hline 10 & 63 & Acute-on-chronic bronchitis and emphysema \\
\hline 11 & 55 & Coronary thrombosis \\
\hline 12 & 89 & Carcinoma of bronchus \\
\hline 13 & 62 & $\begin{array}{l}\text { Pulmonary embolus and cerebrovascular } \\
\text { disease }\end{array}$ \\
\hline 14 & 69 & $\begin{array}{l}\text { Myocardial degeneration, ischaemic heart } \\
\text { disease, atherosclerosis }\end{array}$ \\
\hline 15 & 55 & Coronary occlusion due to atheroma \\
\hline \multicolumn{3}{|l|}{ Female } \\
\hline 16 & 70 & $\begin{array}{l}\text { Rheumatic heart disease and congestive } \\
\text { cardiac failure }\end{array}$ \\
\hline 17 & 79 & Bronchopneumonia \\
\hline 18 & 82 & Renal papillary necrosis \\
\hline 19 & 59 & Carcinoma of breast \\
\hline 20 & 88 & $\begin{array}{l}\text { Coronary thrombosis-chronic } \\
\text { pyelonephritis }\end{array}$ \\
\hline
\end{tabular}

${ }^{*}$ Confirmed by death certificate in every case. deaths for the gouty index patients and their firstdegree relatives.

The observed and expected numbers of deaths were compared in each age stratum, and a Poisson probability curve was used to obtain a $p$ value to indicate whether there was a significant difference between observed and expected death rates.

\section{Results}

All causes of death for gouty index patients are shown in Table 1.

For male gouty index patients the results obtained by comparing expected and observed coronary artery deaths are shown in Table 2 . Among male gouty index patients after presentation to hospital there were 5 deaths from coronary disease, all occurring after the age of 55 years and not significantly more than the expected number for the general population of that age. Numbers of female gouty index patients were too small for statistical analysis.

Results for male and female first-degree relatives of gout patients are shown in Tables 3 and 4 . Here also there was no significantly increased incidence of deaths from coronary artery disease in comparison with the general population.

When deaths from cerebrovascular disease were considered among male gouty index patients (Table 1) one cerebrovascular accident, confirmed by a death certificate, was observed, and this incidence

Table 2 Coronary artery deaths among male gout patients

\begin{tabular}{lllll}
\hline $\begin{array}{l}\text { Age in } \\
\text { years }\end{array}$ & $\begin{array}{l}\text { No. of years } \\
\text { at risk }\end{array}$ & $\begin{array}{l}\text { Expected } \\
\text { coronary } \\
\text { artery } \\
\text { deaths }\end{array}$ & $\begin{array}{l}\text { Observed } \\
\text { coronary } \\
\text { artery } \\
\text { deaths }\end{array}$ & Significance \\
\hline$<55$ & 530 & 0 & 0 & NS \\
55 & 529 & 4.5 & 5 & NS \\
$\begin{array}{l}\text { and over } \\
\text { All ages }\end{array}$ & 1059 & 4.5 & 5 & NS \\
\hline
\end{tabular}

NS $=$ not significant

Table 3 Coronary artery deaths among male first-degree relatives of gout patients

\begin{tabular}{ccccc}
\hline $\begin{array}{l}\text { Age in } \\
\text { years }\end{array}$ & $\begin{array}{l}\text { No. of years } \\
\text { at risk }\end{array}$ & $\begin{array}{l}\text { Expected } \\
\text { coronary } \\
\text { artery } \\
\text { deaths }\end{array}$ & $\begin{array}{l}\text { Observed } \\
\text { coronary } \\
\text { artery } \\
\text { deaths }\end{array}$ & Significance \\
\hline$<55$ & 8616 & $4 \cdot 31$ & 3 & NS \\
55 & 2976 & $20 \cdot 83$ & 21 & NS \\
$\begin{array}{l}\text { and over } \\
\text { All ages }\end{array}$ & 11592 & $25 \cdot 14$ & 24 & NS \\
\hline
\end{tabular}

NS $=$ not significant 
Table 4 Coronary artery deaths among female first-degree relatives of gout patients

\begin{tabular}{lrlll}
\hline $\begin{array}{l}\text { Age in } \\
\text { years }\end{array}$ & $\begin{array}{l}\text { No. of years } \\
\text { at risk }\end{array}$ & $\begin{array}{l}\text { Expected } \\
\text { coronary } \\
\text { artery } \\
\text { deaths }\end{array}$ & $\begin{array}{l}\text { Observed } \\
\text { coronary } \\
\text { artery } \\
\text { deaths }\end{array}$ & Significance \\
\hline$<55$ & 7884 & 0.53 & 0 & NS \\
55 & 3316 & $9 \cdot 29$ & 12 & NS \\
and over & 31200 & 9.82 & 13 & NS \\
All ages & 11200 \\
\hline
\end{tabular}

NS = not significant.

Table 5 Cerebrovascular deaths among male first-degree relatives of gout patients

\begin{tabular}{lcccc}
\hline $\begin{array}{l}\text { Age in } \\
\text { years }\end{array}$ & $\begin{array}{l}\text { No. of years } \\
\text { at risk }\end{array}$ & $\begin{array}{l}\text { Expected } \\
\text { no. of } \\
\text { cerebro- } \\
\text { vascular } \\
\text { deaths }\end{array}$ & $\begin{array}{l}\text { Observed } \\
\text { no. of } \\
\text { cerebro- } \\
\text { vascular } \\
\text { deaths }\end{array}$ & Significance \\
\hline$<55$ & 8616 & 1.32 & 3 & NS \\
55 & 2975 & 12.60 & 12 & NS \\
$\begin{array}{c}\text { and over } \\
\text { All ages }\end{array}$ & 11591 & 13.92 & 15 & NS \\
\hline
\end{tabular}

NS $=$ not significant.

Table 6 Cerebrovascular deaths among female first-degree relatives of gout patients

\begin{tabular}{lcccc}
\hline $\begin{array}{l}\text { Age in } \\
\text { years }\end{array}$ & $\begin{array}{l}\text { No. of years } \\
\text { at risk }\end{array}$ & $\begin{array}{l}\text { Expected } \\
\text { no. of } \\
\text { cerebro- } \\
\text { vascular } \\
\text { deaths }\end{array}$ & $\begin{array}{l}\text { Observed } \\
\text { no. of } \\
\text { cerebro- } \\
\text { vascular } \\
\text { deaths }\end{array}$ & Significance \\
\hline$<55$ & 7884 & 1.1 & 2 & NS \\
55 & 3316 & 12.43 & 9 & NS \\
$\begin{array}{l}\text { and over } \\
\text { All ages }\end{array}$ & 11200 & 13.53 & 11 & NS \\
\hline
\end{tabular}

NS = not significant.

does not differ significantly from expected values for the general population. Numbers of female gouty index patients were too small for statistical analysis.

Data from male and female first-degree relatives of gout patients are shown in Tables 5 and 6 . These results show that neither male nor female first-degree relatives of gout patients have an increased risk of dying from cerebrovascular disease in comparison with the population at large.

Since lipid levels had been analysed previously in the families of these 180 gouty index patients and their first-degree relatives ${ }^{8}$ and had shown raised serum levels of pre- $\beta$-lipoproteins and triglycerides, with reduction in the proportion of $\beta$-lipoproteins in the gout patients, though not in their relatives, it was thought important to know whether there was an increased incidence of coronary or cerebrovascular disease in the families of the 35 gout patients who had been found to be hyperlipidaemic - that is, with cholesterol and/or triglyceride levels beyond the 95th percentile of a normal population of a known age and sex.

Examination of data from the families of 35 hyperlipidaemic gout patients revealed the deaths of 7 males and 3 females from coronary artery disease and the deaths of 3 males and 2 females from cerebrovascular disease.

When comparison was made between families of the hyperlipidaemic and normalipidaemic gout patients the data revealed a slight increase in male deaths from coronary artery disease in the hyperlipidaemic group but no other mortality differences. This increased death rate may reflect the significant hypercholesterolaemia which was found among both male and female relatives of hyperlipidaemic index patients. ${ }^{8}$

Such hyperlipidaemia would be expected in families of hyperlipidaemic index patients in the same way as an increase in height is found among relatives of tall index patients, and, particularly since the hyperlipidaemia is a hypercholesterolaemia and not the hypertriglyceridaemia which usually is associated with gout, the hypercholesterolaemia may well be causally unrelated to the gout although affecting the vascular mortality in these families.

\section{Discussion}

The reason why this mortality study differed in its results from other studies ${ }^{6}$ in not finding an increased risk of vascular disease associated with hyperuricaemia can only be the subject of hypothesis. However, the Framingham Heart Study ${ }^{6}$ was not designed specifically to investigate gout patients and therefore may not be directly comparable. Furthermore, the multifactorial pathogenesis of hyperuricaemia and gout is now well recognised. Any group of gout patients may include a variety of pathological entities, and it is therefore not surprising if various authors investigating different hyperuricaemic and gouty groups obtain discrepant results.

The possible role of hyperuricaemia in the genesis of vascular disease is still under discussion, but the evidence so far indicates that hyperuricaemia, in the absence of other factors such as smoking and hypertension, is not an independent coronary risk factor-a concept in accord with the findings of the present study.

There is considerable current interest in the role of 
high density lipoproteins (HDL) in protection against vascular disease.$^{10}{ }^{11}$ Our own failure ${ }^{8}$ to show a significant difference between HDL proportions in this same group of gouty index patients and those of controls suggests that HDL do not play a significant part in protecting these gout patients from vascular disease.

In contrast, however, we found that the increased proportion of pre- $\beta$-lipoproteins in male gout patients corresponded to the reduction in the proportion of the B-lipoprotein. Since B-lipoprotein is the lipoprotein primarily involved in the transport of cholesterol, the lipid most incriminated in the aetiology of coronary heart disease ${ }^{12}$ it is possible that the reduction in $\beta$-lipoprotein, corresponding to the elevation in pre- $\beta$-lipoprotein in gout patients, may be one reason why their death rate from coronary artery and cerebrovascular disease has not been shown to be increased.

Finally it should be remembered that the hyperlipidaemia of gout is a hyperprebetalipoproteinaemia reflected by hypertriglyceridaemia which, although believed to increase the risk of ischaemic heart disease ${ }^{13-15}$ is also though to be a much less serious risk factor for vascular disease than hypercholesterolaemia. ${ }^{16}$ Indeed, in the Albany Study ${ }^{17}$ hypertriglyceridaemia was regarded as possibly exerting an additive effect to that of hypercholesterolaemia rather than acting independently.

There are certain inevitable limitations to this study. Firstly, we cannot comment on the mortality rate of hyperlipidaemic index patients, since they are still living. Secondly, we cannot comment on lipid levels in dead, gouty index patients, since they died before the study began and their lipid data are unknown. Thirdly, although there is no evidence that hypouricaemic therapy protects patients from vascular disease, it should be emphasised that most of the index cases in this study had received such treatment, and the possibility of a protective effect cannot be excluded.

With these limitations, however, it may be siad that our failure to demonstrate an increased mortality from cardiovascular causes in patients with gout indicates the likelihood that patients with hyperuricaemia and gout alone are not at serious risk of vascular disease. Additional risk factors may be present in these patients, however, such as hyperlipidaemia and hypertension. It is important that such risk factors should be identified and, if necessary, treated in addition to the management of the hyperuricaemia itself.

L.G.D. gratefully acknowledges the support from a Trustees' Research Fellowship from Charing Cross Hospital, London, at the time when this study was performed.

\section{References}

1 Myers A R, Epstein F H, Dodge H J, Mikkelsen W M. The relationship of serum uric acid to risk factors in coronary heart disease. Am J Med 1968; 45: 520-8.

2 Klein R, Klein B E, Cornoni J C, et al. Serum uric acid, its relationship to coronary heart disease risk factors and cardiovascular disease, Evans County, Georgia. Arch Intern Med 1973; 132: 401-10.

3 Vabusek M. Hyperuricaemia and coronary heart diseases.J Clin Chem Clin Biochem 1979; 17: 448.

4 Ungerleider H E. The internist and life insurance. Ann Intern Med 1954; 41: 124-30.

5 Talbott J H, Lilienfeld A. Longevity in gout. Geriatrics 1959; 14: 409-20.

6 Hall A P. Correlations among hyperuricaemia, hypercholesterolaemia, coronary disease and hypertension. Arthritis Rheum 1965; 8: 846-52.

7 Ogryzlo M A. Gout-its effect on morbidity and mortality. Proceedings of the 21st Annual Meeting of the Canadian Life Insurance Medical Officers Association. Toronto, 24 March 1966: 71-9.

8 Darlington L G, Slack J, Scott J T. Family study of lipid and purine levels in gout patients. Ann Rheum Dis 1982; 41: 253-6.

9 Slack J, Evans K A. The increased risk of death from ischaemic heart disease in first-degree relatives of 121 men and 96 women with ischaemic heart disease. $J$ Med Genet 1966; 3: 239-57.

10 Miller G J, Miller N E. Plasma-high-density-lipoprotein concentration and development of ischaemic heart disease. Lancet 1975; i: 16-9.

11 Glueck C J, Gartside P, Fallat R W, Sielski J, Steiner P M. Longevity syndromes: familial hypobeta and familial hyperalpha lipoproteinaemia. J Lab Clin Med 1976; 88: 941-57.

12 Kannel W B, Dawber T R, Friedman G D, Glennon W E, McNamara $P$ M. Risk factors in coronary heart disease. An evaluation of several serum lipids as predictors of coronary heart disease. The Framingham Study Ann Intern Med 1964; 61: 888-99.

13 Rosenman R H, Friedman M, Straus R, Jenkins C D, Zyzanski S J, Wurm M. Coronary heart disease in the western collaborative group study. J Chron Dis 1970; 23: 173-90.

14 Carslon L A, Böttiger L E. Ischaemic heart disease in relation to fasting values of plasma triglycerides and cholesterol. Lancet 1972; i: 865-8.

15 Pelkonen R, Nikkilä E A, Koskinen S, Penttinen K, Sarna S. Association of serum lipids and obesity with cardiovascular mortality. Br Med J 1977; ii: 1185-7.

16 Gordon T, Castelli W P, Hjortland M C, Kannel W B, Dawber T R. High density lipoprotein as a protective factor against coronary heart disease. The Framingham Study. Am J Med 1977; 62: 707-14.

17 Brown D F. Blood lipids and lipoproteins in atherogenesis. Am J Med 1969; 46: 691-704. 